\title{
KANDUNGAN KOPI KEDELAI LAUWON KECAMATAN LUWUK TIMUR KABUPATEN BANGGAI
}

\author{
Ramadhani Chaniago ${ }^{*}$, Bakri Muala ${ }^{2}$ \\ ${ }^{1}$ Program Studi Agroteknologi, Universitas Muhammadiyah Luwuk, Indonesia \\ ${ }^{2}$ Program Studi Agribisnis, Universitas Muhammadiyah Luwuk, Indonesia \\ Co-author:idhon86chaniago@gmail.com
}

\begin{tabular}{l} 
Paper Information \\
History: \\
Received : 15-08- 2020 \\
Accepted : 20-09-2020 \\
\hline
\end{tabular}

Keywords:

Soybean coffee Lauwon soybean East Luwuk

\begin{abstract}
Abstrak: Kedelai merupakan bahan yang banyak manfaatnya dan diinformasikan tidak memiliki kandungan kafein sehingga baik dan aman bila dikonsumsi oleh anak-anak, ibu hamil, dan orang -orang yang memiliki penyakit pencernaan. Penelitian ini bertujuan untuk mengetahui kandungan kopi kedelai yang dihasilkan oleh masyarakat Desa Lauwon Kecamatan Luwuk Timur Kabupaten Banggai Propinsi Sulawesi Tengah. Penelitian ini dilaksanakan pada bulan April sampai Agustus 2020 yang terdiri dari 2 tahapan yaitu : 1) tahapan pertama, pembuatan kopi kedelai yang dilakukan oleh masyarakat Desa Lauwon Kecamatan Luwuk Timur Kabupaten Banggai Propinsi Sulawesi Tengah. 2) tahapan kedua, pengujian laboratorium di Laboratorium Penelitian dan Pengujian Terpadu (LPPT) UGM Yogyakarta. Hasil penelitian menunjukkan bahwa kopi kedelai Lauwon tidak mengandung kafein (non-caffeine) dan mengandung kadar air (3,42\%), protein (31,26\%), lemak total $(0,95 \%)$, total gula $(0,50 \%)$, timbal $(\mathrm{Pb})$ tidak terdeteksi, tembaga $(\mathrm{Cu})(13,97 \mathrm{mg} / \mathrm{kg})$, seng (Zn) $(52,99 \mathrm{mg} / \mathrm{kg})$, merkuri $(\mathrm{Hg}) 0,04 \mathrm{mg} / \mathrm{kg}$, angka cemaran bakteri (ALT) $2,0 \times 10^{3} \mathrm{cfu} / \mathrm{gram}$ dan Aktivitas penangkapan radikal bebas DPPH (IC50) $2,467 \mathrm{mg} / \mathrm{mL}$.
\end{abstract}

\begin{abstract}
Soybean is an ingredient that has many benefits and is informed that it does not contain caffeine, so it is good and safe for consumption by children, pregnant women, and people who have digestive diseases. This study aims to determine the content of soy coffee produced by the people of Lauwon Village, East Luwuk District, Banggai Regency, Central Sulawesi Province. This research was conducted from April to August 2020 which consisted of 2 stages, namely: 1) the first stage, the manufacture of soy coffee which was carried out by the people of Lauwon Village, Luwuk Timur District, Banggai Regency, Central Sulawesi Province. 2) the second stage, laboratory testing at the Integrated Research and Testing Laboratory (LPPT) UGM Yogyakarta. The results showed that Lauwon soybean coffee does not contain caffeine (non-caffeine) and contains water content (3.42\%), protein $(31.26 \%)$, total fat (0.95\%), total sugar (0.50\%). ), lead (Pb) was not detected, copper (Cu) (13.97 mg / $\mathrm{kg})$, zinc $(\mathrm{Zn})(52.99 \mathrm{mg} / \mathrm{kg})$, mercury $(\mathrm{Hg}) 0.04 \mathrm{mg} / \mathrm{kg}$, bacterial contamination rate ( $\mathrm{ALT}$ ) $2.0 \times 103 \mathrm{cfu} / \mathrm{gram}$ and DPPH free radical scavenging activity (IC50) $2.467 \mathrm{mg} / \mathrm{mL}$.
\end{abstract}

\section{A. LATAR BELAKANG}

Kedelai (Glycine max L. Mer) merupakan jenis kacang-kacangan yang paling banyak dikonsumsi dan sebagai sumber protein nabati terpenting di Indonesia. Ditinjau dari sisi pangan dan gizi, kedelai merupakan sumber protein yang paling murah di dunia, selain sebagai sumber minyak yang bermutu tinggi. Biji kedelai utuh, maupun telah menjadi tepung dapat diolah beranekaragam produk pangan, pakan ternak, maupun produk untuk berbagai keperluan industri. Kedelai yang banyak dibudidayakan di Indonesia adalah kedelai kuning yang memiliki kandungan protein $34,22 \%$. Kandungan protein dalam kedelai lebih tinggi dibanding protein pada ayam 23.4\%. ikan 18.3\%. susu segar 3.6\% dan telur 12.9\% (Mudjisihono, 2001). 
Pada umumnya kedelai diolah menjadi beberapa olahan seperti direbus, disangrai ataupun digoreng. Kedelai rebus biasanya dipilih kedelai muda dan direbus dalam bentuk polong. Selain itu kedelai yang dikecambahkan, dikonsumsi sebagai sayur. Perbaikan penanganan pasca panen kedelai yang ditunjang paket peralatan yang tepat. dengan penggunaan teknologi yang inovatif akan lebih mudah diterima oleh petani. Kedelai sebagian besar dikonsumsi oleh masyarakat dalam bentuk olahan dan hanya sebagian kecil yang dikonsumsi secara langsung. Salah satu upaya pemanfaatan kedelai adalah dengan mengolah kedelai menjadi minuman (Mudjisihono, 2000). Pembuatan minuman kedelai tersebut melalui proses roasting seperti halnya dalam pembuatan kopi bubuk.

Konsumsi kopi telah dikenal begitu luas dewasa ini, dan berbagai peringatan dari para ahli telah berulang kali diungkapkan selama bertahun-tahun terhadap banyaknya bahaya yang mengancam para peminum kopi.

Hasil penelitian menunjukkan bahwa para penikmat kopi harus mewaspadai bahaya yang dapat ditimbulkan dari kebiasaan minum kopi. Kopi mengandung kafein, yang dalam dosis rendah dapat mengurangi rasa lelah dan membuat pikiran jadi segar. Padahal kemajuan ilmu pengetahuan menunjukkan bahwa konsumsi kopi dalam jumlah yang besar berpengaruh tidak baik bagi kesehatan. Ini disebabkan kafein jika dikonsumsi dalam jumlah tinggi cepat mempengaruhi sistem saraf pusat, sistem pernapasan, otot, pembuluh darah, jantung dan ginjal pada manusia dan hewan.

Studi deskriptif oleh (Bawazeer and AlSobahi, 2013) menunjukkan bahwa $34,3 \%$ peminum minuman energi yang mengandung kafein mengaku mengalami efek samping diantaranya palpitasi, insomnia, nyeri kepala, tremor, gelisah, serta mual dan muntah.

Jumlah yang boleh dikonsumsi adalah $300 \mathrm{mg}$ kafein atau setara dengan 3 cangkir kopi perhari. Kecanduan terhadap kafein diperkirakan jika mengkonsumsi lebih dari $600 \mathrm{mg}$ kafein atau setara dengan 5-6 cangkir kopi perhari selama 8-15 hari berturut-turut. Sedangkan dosis yang dapat berakibat fatal bagi manusia adalah sekitar 10 gram kafein atau 20-50 cangkir perhari (Sofiana, 2011).

Kedelai merupakan bahan yang bergizi tinggi dan disinyalir tidak memiliki kandungan kafein sehingga baik apabila dikonsumsi sehari-hari. Kedelai sangat aman dikonsumsi oleh anak-anak, ibu hamil, dan orang -orang yang memiliki penyakit pencernaan. Menurut (Mudjisihono, 2000) bahwa produk minuman dari bubuk kedelai yang melalui proses penyangraian diharapkan menjadi salah satu alternatif pengganti kopi non-kafein dan tidak menimbulkan efek samping bagi kesehatan manusia, bahkan kopi kedelai hitam dapat dikonsumsi oleh orang yang memiliki penyakit diabetes.

Dilihat dari segi pangan dan gizi, kedelai merupakan sumber protein yang paling murah di dunia dan lebih terjangkau dibanding dengan sumber protein lain. Kedelai mengandung protein $35 \%$ bahkan dapat mencapai 40-43\% pada varietas unggul, dibandingkan dengan beras, jagung, tepung singkong, kacang hijau, daging, ikan segar, dan telur ayam, kedelai mempunyai kandungan protein yang lebih tinggi, hampir menyamai kadar protein susu skim kering (Setiavani and di STPP Medan, 2012).

Berdasarkan hal-hal diatas, maka perlu adanya kegiatan penelitian terkait dengan kandungan kopi kedelai yang dihasilkan oleh masyarakat Desa Lauwon Kecamatan Luwuk Timur Kabupaten Banggai Propinsi Sulawesi Tengah. Dengan adanya informasi tentang kandungan gizi dari kopi kedelai lauwon maka akan memberikan sumbangsih pengetahuan dalam upaya pengembangan desa sentra olahan kedelai.

\section{B. METODE PENELITIAN}

Penelitian ini dilaksanakan pada bulan April sampai Agustus 2020 yang terdiri dari 2 tahapan yaitu : 1) tahapan pertama, pembuatan kopi kedelai yang dilakukan oleh masyarakat Desa Lauwon Kecamatan Luwuk Timur Kabupaten Banggai Propinsi Sulawesi Tengah. 2) tahapan kedua, pengujian laboratorium di Laboratorium Penelitian dan Pengujian Terpadu (LPPT) UGM Yogyakarta. Berikut tahapan penelitian ini dilaksanakan :

\section{Pembuatan Kopi Kedelai}

Proses pembuatan kopi kedelai meliputi: persiapan alat dan bahan, penyortiran, pencucian, penyangraian, penggilingan, pengayakan, dan pengemasan. Berikut penjelasan proses pembuatan kopi kedelai.

\section{Persiapan Alat dan Bahan}

Alat yang digunakan dalam pembuatan kopi kedelai adalah wadah penampung kedelai seperti Loyang ataupun ember, peniris air, wajan, kompor gas, sendok masak, alat penggiling listrik, ayakan, kemasan, sealer. Sedangkan bahan yang digunakan adalah kacang kedelai lokal Desa Lauwon yang berwarna kuning.

\section{Perlakuan pendahuluan}

Meliputi penyortiran adalah memisahkan biji yang berkualitas baik dengan biji yang berkualitas kurang baik, tujuannya adalah untuk mendapatkan kualitas yang baik pada produk kopi kedelai.

\section{Pencucian dengan Air Bersih \& Penirisan}

Pencucian bertujuan untuk menghilangkan kotoran yang melekat maupun tercampur di antara biji kedelai. Penirisan bertujuan untuk mengeringkan biji kedelai yang telah dicuci dengan air bersih.

\section{Penyangraian (Roasting)}

Kegiatan penyangraian (roasting) ini menjadi langkah yang sangat menentukan kualitas dari produk kopi kedelai ini karena fungsi dari penyangraian (roasting) adalah untuk mengeluarkan aroma dan juga citarasa kopi. Tanpa disangrai biji kopi aromanya seperti umumnya biji-bijian. Tetapi ketika disangrai aromanya menjadi wangi. Kegiatan penyangraian ini 
dilakukan selama 30 menit dengan suhu $\pm 102,3{ }^{\circ} \mathrm{C}$ menggunakan wajan dan sendok pengaduk berbahan stainless steel. Setelah disangrai kemudian didiamkan sejenak untuk menurunkan suhu atau pendinginan setelah penyangraian.

\section{Penggilingan}

Setelah didiamkan selama \pm 15 menit kemudian dilanjutkan dengan kegiatan penggilingan atau penghalusan biji kedelai yang telah disangarai menjadi bubuk dengan menggunakan alat penggiling kopi listrik (coffee grinder) CG-60o. Setelah halus menjadi bubuk kopi kedelai maka proses selanjutnya dilakukan pengayakan dengan menggunakan ayakan.

\section{Pangayakan/Ditapis}

Setelah halus menjadi bubuk kopi kedelai maka proses selanjutnya dilakukan pengayakan dengan menggunakan ayakan tepung. Pengayakan berfungsi untuk memisahkan hasil bubuk kopi kedelai yang belum halus kemudian digiling kembali.

\section{Pengemasan}

Tujuan utama dari pemberian kemasan pada produk adalah untuk melindungi dan mencegah kerusakan. Selain itu, dapat menjadi sarana informasi dan pemasaran yang baik dengan membuat

Tabel 1.

Hasil Uji Laboratorium dan Syarat Mutu Bubuk Kopi berdasarkan SNI 01-3542-2004

\begin{tabular}{|c|c|c|c|}
\hline No & Kriteria Uji & Hasil Uji & $\begin{array}{l}\text { Syarat Mutu Bubuk Kopi } \\
\text { (SNI o1-3542-2004) }\end{array}$ \\
\hline 1. & Kadar Air & $3,42 \%$ & Maksimal $7 \%$ \\
\hline 2. & Kaffein (anhidrat) & Tidak terdeteksi & $0,45-2 \% \mathrm{~b} / \mathrm{b}$ \\
\hline 3. & \begin{tabular}{ll}
\multicolumn{2}{l}{ Cemaran Logam } \\
- & Timbal $(\mathrm{Tb})$ \\
- & Tembaga $(\mathrm{Cu})$ \\
- & Seng $(\mathrm{Zn})$ \\
- & Timah $(\mathrm{Sn})$ \\
- & Raksa $(\mathrm{Hg})$ \\
\end{tabular} & $\begin{array}{l}\text { Tidak terdeteksi } \\
13,97 \mathrm{mg} / \mathrm{kg} \\
52,99 \mathrm{mg} / \mathrm{kg} \\
\text { (belum diteliti) } \\
0,04 \mathrm{mg} / \mathrm{kg} \\
\text { (belum diteliti) }\end{array}$ & $\begin{array}{c}\text { Maksimal 2,0 mg/kg } \\
\text { Maksimal 30,0 mg/kg } \\
\text { Maksimal 40,0 mg/kg } \\
\text { Maksimal 40,0/250,0 mg/kg } \\
\text { Maksimal o,03 mg/kg } \\
\text { Maksimal 1,0 mg/kg }\end{array}$ \\
\hline 4. & $\begin{array}{l}\text { Cemaran mikroba } \\
\text { - } \quad \text { Angka cemaran bakteri (ALT) } \\
\text { - } \quad \text { Kapang }\end{array}$ & $\begin{array}{l}\text { 2,o x } 10^{3} \mathrm{cfu} / \mathrm{gram} \\
\text { (belum diteliti) }\end{array}$ & $\begin{array}{l}\text { Maksimal } 10^{6} \mathrm{koloni} / \mathrm{g} \\
\text { Maksimal } 10^{4} \mathrm{koloni} / \mathrm{g}\end{array}$ \\
\hline 5. & $\begin{array}{l}\text { Aktivitas penangkapan radikal bebas DPPH } \\
\text { (IC50) }\end{array}$ & $2,467 \mathrm{mg} / \mathrm{mL}$ & - \\
\hline 6. & Protein & $31,26 \%$ & - \\
\hline 7. & Lemak total & $0,95 \%$ & - \\
\hline 8. & Total Gula & $0,50 \%$ & - \\
\hline
\end{tabular}

Dari hasil pengujian laboratorium pada Tabel 1 menunjukkan bahwa kandungan kopi kedelai Lauwon mengandung protein $31,26 \%$, lemak total $0,95 \%$, dan Total Gula $0,50 \%$. Sedangkan untuk cemaran logam seperti : timbal $(\mathrm{Pb})$, tembaga $(\mathrm{Cu})$, seng $(\mathrm{Zn})$ hasilnya masih dibawah dari syarat mutu bubuk kopi SNI 013542-2004 kecuali pada raksa atau merkuri yang nilainya masih diatas dari syarat mutu bubuk kopi SNI 01-3542-2004. Peristiwa ini dimungkinkan karena faktor alat produksi seperti alat masak (wajan dan sendok pengaduk) pada saat melakukan proses desain kemasan yang kreatif sehingga lebih menarik dan mudah diingat konsumen.

\section{HASIL DAN PEMBAHASAN}

1. Produk kopi kedelai

Produk bubuk kopi kedelai yang telah dihasilkan memiliki penampakan fisik berwarna cokelat dengan aroma khas kopi. Penampakan fisik kopi kedelai dapat dilihat pada Gambar 1.

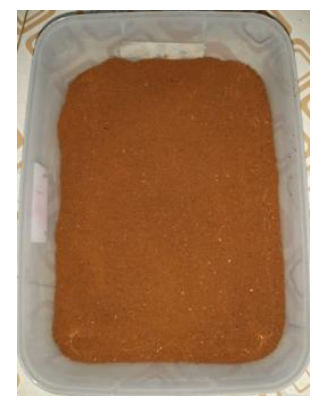

Gambar 1. Bubuk Kopi Kedelai

\section{Hasil Pengujian Laboratorium}

Berdasarkan hasil uji laboratorium, diketahui bahwa kopi kedelai Lauwon memiliki kandungan seperti yang disajikan pada Tabel 1 . 
dari asap kendaraan bermotor, dan asap serta limbah dari pabrik.Logam berat tidak dapat didegradasi dan cenderung diakumulasi di dalam organisme sehingga dapat menimbulkan berbagai macam penyakit dan kerusakan ( $\mathrm{Yu}$ et al., 2013); (Zhuang et al., 2013). Upaya lain yang dapat dilakukan untuk mengurangi cemaran limbah merkuri yaitu dengan cara fitoremediasi (Rondonuwu, 2014); (Baroroh, 2017); (Nainggolan et al., 2018); (Rahmawati, Zaman and Purwono, 2016); (Riswan, Harun and Irsan, 2015). Fitoremediasi merupakan teknik mereduksi tanah atau perairan yang terkontaminasi limbah B3 menggunakan tanaman (Bokhari et al., 2016); (Novita, Hermawan and Wahyuningsih, 2019); (Suharto, Wirosoedarmo and Sulanda, 2018). Cara penyerapan tanaman dalam proses fitoremediasi terdiri atas phytoaccumulation, phytostabilization, rhyzodegradation, rhizoremediation, phytotransformation, phytodegradation, phytovolatization (Purakayastha and Chhonkar, 2010) (Irawanto, 2010); (Singh and Singh, 2017). Metode ini sangat inovatif, ekonomis, mudah dilakukan dan relatif lebih ramah terhadap lingkungan sekitarnya (Sidauruk and Sipayung, 2015). Selain itu, kegiatan fitoremediasi tanah dengan tanaman Celosia plumosa (Voss) Burv mampu menurunkan kandungan Mercuri (Hg) tanah bahkan untuk tanah sawah dan kebun sudah dibawah nilai ambang batas kandungan logam berat alami pada tanah (Juhriah and Alam, 2016).

Untuk Angka Cemaran Bakteri (ALT) 2,0 x 103 cfu/gram atau masih dibawah persayaratan SNI o13542-2004. Untuk uji Aktivitas penangkapan radikal bebas DPPH (IC5O) sebesar $2,467 \mathrm{mg} / \mathrm{mL}$, artinya untuk menangkal radikal bebas sebanyak 50\% kopi kedelai tersebut hanya membutuhkan 2,467 mg utk setiap $\mathrm{mL}$ nya, jika kopi kedelai tersebut dibaca sebagai vitamin C. Dibaca sebagai vitamin C karena standar pembanding uji antioksidannya menggunakan vitamin C. Untuk golongan antioksidannya termasuk dalam kategori antioksidan lemah, karena hasilnya diatas 150 mikrogram $/ \mathrm{mL}$. Sedangkan standar vitamin $\mathrm{C}$, itu nilai IC50nya sekitaran 2-3 mikrogram $/ \mathrm{mL}$. Suatu senyawa dikatakan sebagai antioksidan sangat kuat jika nilai IC50 kurang dari 50, kuat (50-100), sedang (100-150), dan lemah (151-200).Semakin kecil nilai IC50 semakin tinggi aktivitas antioksidan. (Badarinath et al., 2010).

Untuk uji kaffein dengan limit deteksi $1,40 \mu \mathrm{g} / \mathrm{g}$ menunjukkan bahwa tidak terdapat kaffein dalam bubuk kopi kedelai Luwon, ini menginformasikan bahwa kopi kedelai Lauwon bebas dari kafein (noncaffeine) yang apabila mengkonsumsinya dapat terhindar dari beberapa penyakit pada tubuh manusia. Mengkonsumsi kafein dalam jumlah besar dan frekuensi berlebih dapat menyebabkan tubuh mengalami semacam ketagihan atau kecanduan (Sofwan, 2013). Konsumsi kafein sebaiknya tidak melebihi 150 mg sehari. Menurut SNI 01-7152- 2006 batas maksimum kafein adalah $150 \mathrm{mg} /$ hari dan 50 $\mathrm{mg} / \mathrm{sajian}$. Tapi, mengkonsumsi kafein sebanyak 100 mg tiap hari dapat menyebabkan individu tersebut tergantung pada kafein. Maksudnya, seseorang dapat mengalami gejala seperti rasa lelah, perasaan terganggu atau sakit kepala jika ia tiba - tiba berhenti mengkonsumsi kafein.

Konsumsi kafein dalam dosis rendah memang terbukti memberikan manfaat. Dalam sebuah studi oleh Smit dan Rogers (2000) dalam (Megananda, Arlianni and Mawardani, 2019) dikatakan bahwa 12,5 - $100 \mathrm{mg}$ kafein dapat memberikan efek positif dan jarang menimbulkan efek samping. Namun tidak semua produk berkafein seperti kopi dan minuman energi mencantumkan kadar kafein yang terkandung didalamnya. Kadar kafein pada minuman energi cukup tinggi yaitu sekitar 80 - $141 \mathrm{mg}$ per sajian (Norton, Lazev and Sullivan, 2011), (Küçer, 2010).

\section{SIMPULAN DAN SARAN}

Berdasarkan hasil pengujian, maka kopi kedelai Lauwon tidak mengandung kafein (non-caffeine) dan mengandung kadar air (3,42 \%), protein (31,26 \%), lemak total $(0,95 \%)$, total gula (0,50 \%), timbal $(\mathrm{Pb})$ tidak terdeteksi, tembaga $(\mathrm{Cu})(13,97 \mathrm{mg} / \mathrm{kg})$, seng (Zn) $(52,99 \mathrm{mg} / \mathrm{kg})$, merkuri (Hg) 0,04 mg/kg, angka cemaran bakteri (ALT) 2,0 x $10^{3} \mathrm{cfu} /$ gram dan Aktivitas penangkapan radikal bebas DPPH (IC50) $2,467 \mathrm{mg} / \mathrm{mL}$.

\section{UCAPAN TERIMA KASIH}

Ucapan terima kasih kepada Kementerian Riset dan Teknologi dan Badan Riset Inovasi Nasional (KEMENRISTEK-BRIN), Terimakasih kepada Aparat Desa Lauwon yang telah mendukung penelitian ini dari awal sampai dengan selesai serta adanya dukungan dari semua pihak yang telah membantu sehingga penelitian ini berjalan dengan baik dan lancar.

\section{DAFTAR RUJUKAN}

Badarinath, A. V et al. (2010) 'A review on in-vitro antioxidant methods: comparisions, correlations and considerations', International Journal of PharmTech Research, 2(2), pp. 1276-1285.

Baroroh, F. (2017) 'Fitoremediasi Air Tercemar Tembaga (Cu) Menggunakan Salvinia molesta Dan Pistia stratiotes Serta Pengaruhnya Terhadap Budidaya Tanaman Brassica rapa'. Universitas Brawijaya.

Bawazeer, N. A. and AlSobahi, N. A. (2013) 'Prevalence and side effects of energy drink consumption among medical students at Umm Al-Qura University, Saudi Arabia', International Journal of Medical Students 
(3), pp. 104-108.

Bokhari, S. H. et al. (2016) 'Phytoremediation potential of Lemna minor L. for heavy metals', International journal of phytoremediation. Taylor \& Francis, 18(1), pp. 25-32.

Irawanto, R. (2010) 'Fitoremidiasi Lingkungan Dalam Taman Bali', Local Wisdom: Jurnal Ilmiah Kajian Kearifan Lokal, 2(4), pp. 29-35.

Juhriah, J. and Alam, M. (2016) 'Fitoremediasi Logam Berat Merkuri (Hg) pada Tanah Dengan Tanaman Celosia Plumosa (Voss) Burv.', BIOMA: JURNAL BIOLOGI MAKASSAR, 1(1).

Küçer, N. (2010) 'The relationship between daily caffeine consumption and withdrawal symptoms: a questionnairebased study', Turkish Journal of Medical Sciences. The Scientific and Technological Research Council of Turkey, 40(1), pp. 105-108.

Megananda, R. C., Arlianni, K. W. and Mawardani, N. A. (2019) 'DIVERSIVIKASI KOPI BIJI MENGKUDU (Morinda citrifolia) SEBAGAI UPAYA PELESTARIAN TANAMAN LOKAL', in Prosiding Seminar Nasional SIMBIOSIS.

Mudjisihono (2000) 'Teknologi Pengolahan Bubuk Kedelai sebagai Minuman. Liptan.', 141(74).

Mudjisihono (2001) 'PENGOLAHAN BUBUK KEDELAI SEBAGAI BAHAN MINUMAN ALTERNATIF', Balai Pengkajian Teknologi Pertanian Jogjakarta.

Nainggolan, R. et al. (2018) 'Pengolahan Air Limbah Domestik dengan menggunakan Tanah Gambut dan Tanaman Air', Jurnal Teknik dan Ilmu Komputer, 7(26), pp. 183-189.

Norton, T. R., Lazev, A. B. and Sullivan, M. J. (2011) 'The "buzz" on caffeine: Patterns of caffeine use in a convenience sample of college students', Journal of caffeine research. Mary Ann Liebert, Inc. 140 Huguenot Street, 3rd Floor New Rochelle, NY 10801 USA, 1(1), pp. 35-40

Novita, E., Hermawan, A. A. G. and Wahyuningsih, S. (2019) 'Komparasi Proses Fitoremediasi Limbah Cair Pembuatan Tempe menggunakan Tiga Jenis Tanaman Air', Jurnal Agroteknologi, 13(01), pp. 16-24

Purakayastha, T. J. and Chhonkar, P. K. (2010) 'Phytoremediation of heavy metal contaminated soils', in Soil heavy metals. Springer, pp. 389-429

Rahmawati, A., Zaman, B. and Purwono, P. (2016) 'Kemampuan Tanaman Kiambang (Salvinia Molesta) dalam Menyisihkan Bod dan Fosfat pada Limbah Domestik (Grey Water) dengan Sistem Fitoremediasi secara Kontinyu'. Diponegoro University.

Riswan, R., Harun, U. and Irsan, C. (2015) 'Keragaman Flora Di Lahan Reklamasi Pasca Tambang Batubara PT Ba Sumatera Selatan (Flora Diversity at Post-coal Mining Reclamation in the PT Ba South Sumatera)', Jurnal Manusia dan lingkungan, 22(2), pp. 160-168.

Rondonuwu, S. B. (2014) 'Fitoremediasi limbah merkuri menggunakan tanaman dan sistem reaktor', Jurnal Ilmiah Sains, 14(1), pp. 52-59.

Setiavani, G. and di STPP Medan, M. P. S. P. (2012) 'INOVASI PEMBUATAN SUSU KEDELE TANPA RASA LANGU'.
Sidauruk, L. and Sipayung, P. (2015) 'Fitoremediasi lahan tercemar di kawasan industri Medan dengan tanaman hias', Pertanian Tropik. University of North Sumatra, 2(2), p. 157093 .

Singh, T. and Singh, D. K. (2017) 'Phytoremediation of organochlorine pesticides: Concept, method, and recent developments', International journal of phytoremediation. Taylor \& Francis, 19(9), pp. 834-843.

Sofiana, N. (2011) '1001 Fakta Tentang Kopi', Yogyakarta: Cahaya Atma Pustaka.

Sofwan, R. (2013) Bugar Selalu di Tempat Kerja. Bhuana Ilmu Populer.

Suharto, B., Wirosoedarmo, R. and Sulanda, R. H. (2018) 'Pengolahan Limbah Batik Tulis dengan Fitoremediasi Menggunakan Tanaman Eceng Gondok (Eichornia crassipes)', Jurnal Sumberdaya Alam dan Lingkungan, 3(1) pp. 14-19.

$\mathrm{Yu}, \mathrm{X}$. et al. (2013) 'Adsorption of heavy metal ions from aqueous solution by carboxylated cellulose nanocrystals', Journal of Environmental Sciences. Elsevier, 25(5), pp. 933-943.

Zhuang, P. et al. (2013) 'Heavy metal contamination in soil and soybean near the Dabaoshan Mine, South China', Pedosphere. Elsevier, 23(3), pp. 298-304 